\title{
NAOMI KLEIN
}

The Shock Doctrine. The Rise of Disaster Capitalism

Allen Lane, Londyn 2007, ss. 558

\section{MARTA DORENDA}

Instytut Politologii UMK

\section{Katastrofalny kapitalizm}

$T^{h}$

he Shock Doctrine jest trzecią książką Naomi Klein - autorki, której No Logo zostało okrzyknięte manifestem antyglobalistów, a ona sama ich rzecznikiem. Warto jednak wspomnieć o budzących kontrowersje okolicznościach wydania The Shock Doctrine. Klein, jednoznacznie kontestująca wszystko, co globalne, zdecydowała się umieścić film promujący publikację w amerykańskich serwisach YouTube oraz MySpace. Fakt, iż właścicielem drugiego z nich jest konserwatysta Rupert Murdoch, zagorzały zwolennik polityki George'a W. Busha oraz wojny w Iraku, nie przeszkodził setkom tysięcy zwolenników autorki zapoznać się z treścią filmu i przyczynić się do rozwoju nowej formy reklamy o globalnym - bo sięgającym wszędzie tam, gdzie dociera Internet - zasięgu.

The Shock Doctrine jest próbą analizy historii rynków na przestrzeni ostatnich pięćdziesięciu lat. Przywołane zostają zagadnienia rozwoju wolnego rynku, transformacji ustrojowej w krajach postkomunistycznych, a także kryzysy gospodarcze mające miejsce w minionym półwieczu. To właśnie one, zdaniem autorki, są siłą napędową „katastrofalnego kapitalizmu”. Tytułowy szok, symbolizujący każdy kryzys, analizuje ona w kilku wymiarach. Punktem wyjścia do rozważań staje się porównanie społeczeństw poddanych różnorodnym trudnościom oraz próbom z ofiarą eksperymentów medycznych, niezdolną do normalnego funkcjonowania po „terapii” elektrowstrząsami. Analizując poglądy Miltona Friedmana oraz Szkoły Chicagowskiej, Klein wysuwa hipotezę, iż kryzysy, jakakolwiek byłaby ich natura, są niezbędne, by państwo, opresyjne wobec społeczeństwa, mogło przeforsować decyzje w normalnych warunkach niemożliwe do przyjęcia - „by to, co politycznie niemożliwe, stało się politycznie nieuniknione". W sytuacji, kiedy 
układ sił w polityce światowej lub warunki naturalne tychże kryzysów nie dostarczają, należy je wywołać, by w obliczu wyższej konieczności rozszerzać funkcje państwa oraz naruszać jego budżet, nie ponosząc konsekwencji. Nieuchronność szoku i pewność, iż dotknie on każdego z nas, jest możliwa dzięki jego trzem wymiarom - pierwszy z nich to wojny, ataki terrorystyczne oraz katastrofy naturalne. Ci, którzy z nich ocaleją, zostaną poddani destrukcyjnym działaniom korporacji oraz polityków. Jednostki, które oprą się i tej sile, zostaną złamane przez policję, armię oraz śledztwa i aresztowania. W rezultacie stworzone zostanie oportunistyczne społeczeństwo, skłonne zaakceptować kolejny szok, jakim będą drastyczne reformy ekonomiczne.

Książka Naomi Klein to niewątpliwie ambitne przedsięwzięcie, które zmobilizuje do działania tych, którzy nie zgadzają się z porządkiem, jakim rządzi się cywilizacja zachodnia, stymulowana przez Stany Zjednoczone. Być może, dzięki marketingowej machinie, przekona ono niezdecydowanych. Nie można jednak nie zauważyć znaczących uchybień, których dopuszcza się autorka. Nie obraca się ona $\mathrm{w}$ kręgach akademickich, a książka nie rości pretensji do naukowości, jednak dziennikarska rzetelność wymaga unikania uproszczeń. Tymczasem Klein posługuje się szeregiem informacji, których prawdziwość trudno podważyć, jednak trudno też przypisać oryginalność ich interpretacji. Kolejne rozdziały The Shock Doctrine powtarzają znane z niezliczonych publikacji slogany wymierzone przeciwko Stanom Zjednoczonym, ich prezydentowi oraz korporacjom. Zarzuty padające $\mathrm{w}$ książce bez wątpienia dotyczą ważkich kwestii - dysproporcji między krajami najbogatszymi a rozwijającymi się, spirali ubóstwa, cynizmu wielkiego biznesu. Nie zmienia to jednak faktu, iż praca Klein nie wnosi nic nowego do dotychczasowych działań nad likwidacją powyższych problemów - przeciwnie, przeredagowaniu ulegają powierzchowne analizy i obiegowe opinie jak np. ta, że ataki z 11 września 2001 roku potraktowano jako pretekst do rozpoczęcia wojny, mającej ratować koniunkturę gospodarczą. Złożone zagadnienia z zakresu makroekonomii i ich historyczny kontekst traktuje się zerojedynkowo, umieszczając po „dobrej” lub „złej” stronie. Ten sposób myślenia prowadzi autorkę do przeprowadzenia prostej linii od kryzysu ekonomicznego w Ameryce Łacińskiej z lat 70. do wydarzeń mających miejsce w irackim więzieniu Abu Ghraib. Trudno oprzeć się wrażeniu stronniczości w doborze faktów i komentarzy potwierdzających obraną tezę, a wydarzenia, które mogłyby wpłynąć na jej niejednoznaczność, ulegają odrzuceniu lub ich wartość zmarginalizowaniu. Interpretacja historii XX w. przypomina raczej teorię spisku knutego przez wielkie korporacje wespół z najbogatszymi krajami świata, w którą według jednego schematu wpisują się dyktatury 
w Chile, Kambodży i krajach afrykańskich, transformacja ustrojowa w Europie Wschodniej oraz wojny toczone przez USA.

Kolejnym problemem, z którym nie poradziła sobie Naomi Klein, rezygnując z rzetelnej analizy problemu na rzecz chwytliwych haseł, jest nietrafny wybór przedmiotu krytyki. Potępiany „katastrofalny kapitalizm” utożsamiany jest ze wszystkim, co związane z gospodarką wolnorynkową. To, co Klein nazywa kapitalizmem, jest jego wypaczoną formą, od dawna krytykowaną nawet przez jego piewców. Trudno orzec czy odrzucone zostają wszelkie mechanizmy kapitalizmu czy jedynie efekty ich zniekształcenia, ponieważ treść pojęcia „ekonomicznego faszyzmu” pozostaje niejasna. Autorka przekłada teorie Friedmana, opracowane dla warunków idealnego rynku, na realia państw rozwijających się, po czym zarzuca im nieskuteczność i wywoływanie katastrofalnych skutków, a samemu twórcy wspomaganie zbrodniczych reżimów. Negując wolnorynkowe instrumenty, dziennikarka nie przeciwstawia im żadnej doktryny zdolnej regulować stosunki polityczno-gospodarcze w skali globalnej.

Naomi Klein i poglądy, które reprezentuje, stały się marką podobną do tych, które piętnowała w No Logo. Co gorsza, sposób, w jaki je wyraża, uległ spłyceniu, by dostosować się do wymogów, jakie stawia rynek, z którym sama walczy. Uboga argumentacja, ignorowanie lub naginanie faktów i miejscami przedziwna retoryka oraz konwencja sensacyjnego dokumentu sprawią zapewne, iż The Shock Doctrine sprzeda się w milionach egzemplarzy i uzyska status kolejnego już objawionego pisma. Trudno jednak, by naiwny antykapitalizm, będący próbą wskrzeszenia ducha studenckich rewolt z lat 60., miał obalić system, który, poddany licznym „szokom”, niewzruszenie tkwi w posadach. 